\title{
Contents of Volume 116 (2012)
}

PAGES

Adornato, G., Phalaris: Literary Myth or Historical Reality? Reassessing Archaic Akragas . . . . . . . .483-506 Ashurov. See Ristvet et al.

Archaeological Institute of America, Awards Presented at the 113th Annual Meeting of the

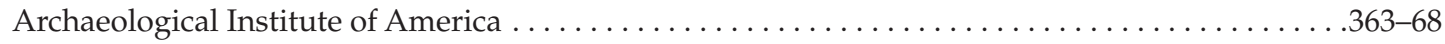

Bakhshaliyev. See Ristvet et al.

Bryant. See Ristvet et al.

Çelik. See Gutzwiller and Çelik.

Counts, D.B., and E. Cova, Book Reviews Editorial Statement. . . . . . . . . . . . . . . . . . . $3-4$

Cova. See Counts and Cova.

Curvers. See Schwartz et al.

Dunham. See Schwartz et al.

Finlayson, C., New Excavations and a Reexamination of the Great Roman Theater at Apamea,

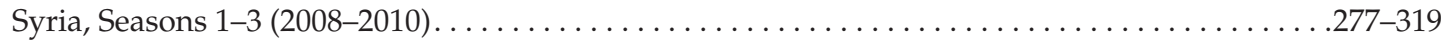

Glatz, C., Bearing the Marks of Control? Reassessing Pot Marks in Late Bronze Age Anatolia . . . . . . . .5-38

Gopnik. See Ristvet et al.

Griffin. See Pitts and Griffin.

Guldager Bilde, P., and S. Handberg, Ancient Repairs on Pottery from Olbia Pontica . . . . . . . . . . .461-81

Gutzwiller, K., and Ö. Çelik, New Menander Mosaics from Antioch . . . . . . . . . . . . . . . . . . .573-623

Handberg. See Guldager Bilde and Handberg.

Keller, D.R., B.A. Porter, and C.A. Tuttle, Archaeology in Jordan, 2010 and 2011 Seasons . . . . . . . . .693-50

Langridge-Noti, E., "This is Sparta”: Recent Publications on Sparta and Laconia ... . . . . . . . . . . .751-55

Lau. See Ristvet et al.

Lavan, L., Public Space in Late Antique Ostia: Excavation and Survey in 2008-2011 . . . . . . . . . . .649-91

Longfellow, B., Roman Fountains in Greek Sanctuaries . . . . . . . . . . . . . . . . . . . . . 133-55

Lord. See Norman and Lord.

Marston, J.M., Agricultural Strategies and Political Economy in Ancient Anatolia . . . . . . . . . . . . . .377-403

Neils, J., University Antiquities Collections: Old and New . . . . . . . . . . . . . . . . . . . . . . . . . .543-48

Neils, J., and P. Schultz, Erechtheus and the Apobates Race on the Parthenon Frieze

(North XI-XII) . . . . . . . . . . . . . . . . . . . . . . . . . . . . . . . . . . . . . . . 195-207

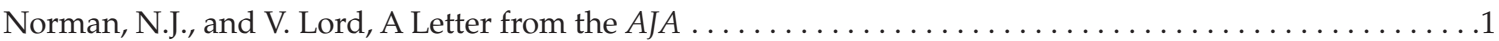

Özen. See Summers and Özen.

Pitts, M., and R. Griffin, Exploring Health and Social Well-Being in Late Roman Britain:

An Intercemetery Approach. . . . . . . . . . . . . . . . . . . . . . . . . . . . . . .

Porter. See Keller et al.

Ristvet, L., H. Gopnik, V. Bakhshaliyev, H. Lau, S. Ashurov, and R. Bryant, On the Edge of

Empire: 2008 and 2009 Excavations at Oğlanqala, Azerbaijan . . . . . . . . . . . . . . . . . . . . . 321-62

Robinson, B.A., "Good Luck” from Corinth: A Mosaic of Allegory, Athletics, and City Identity . . . . . . 105-32

Rothe, U., The "Third Way": Treveran Women's Dress and the "Gallic Ensemble" . . . . . . . . . . . . 235-52

Royal, J.G., Illyrian Coastal Exploration Program (2007-2009): The Roman and Late Roman

Finds and Their Contexts . . . . . . . . . . . . . . . . . . . . . . . . . . . . . . .

Schultz. See Neils and Schultz.

Schwartz, G.M., H.H. Curvers, S.S. Dunham, and J.A. Weber, From Urban Origins to Imperial

Integration in Western Syria: Umm el-Marra 2006, $2008 \ldots \ldots \ldots \ldots \ldots \ldots \ldots \ldots \ldots \ldots \ldots \ldots \ldots$. . . . . . . . . . . . . . . . . . . . . . . . . . . .

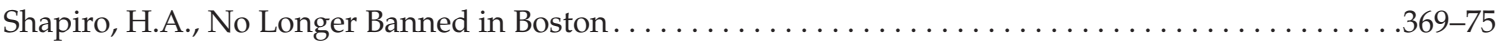


Shaw, J.W., Bathing at the Mycenaean Palace of Tiryns . . . . . . . . . . . . . . . . . . .555-71

Smith, J.S., Seals, Scripts, and Politics at Late Bronze Age Kourion. . . . . . . . . . . . . . . . . . . . . . .39-103

Smith, T.J., Greek Vases: From Artistic Personalities to Archaeological Contexts . . . . . . . . . . . . . . . .549-54

Stirling, L.M., A New Portrait of Livia from Thysdrus (El Jem, Tunisia) . . . . . . . . . . . . . . . .625-47

Summers, G.D., and E. Özen, The Hittite Stone and Sculpture Quarry at Karakız Kasabası and

Hapis Boğazı in the District of Sorgun, Yozgat, Central Anatolia . . . . . . . . . . . . . . . . . . . .507-19

Tuttle. See Keller et al.

Watrous, L.V., The Harbor Complex of the Minoan Town at Gournia. . . . . . . . . . . . . . . . . . . . 521-41

Weber. See Schwartz et al.

Wootton, W., Making and Meaning: The Hellenistic Mosaic from Tel Dor. . . . . . . . . . . . . . . . . . . 209-34

\section{BOOK REVIEWS (open access at www.ajaonline.org)}

Alroth, B., Rev. of Prêtre, ed., Le donateur, l'offrande et la déesse: Systèmes votifs dans les sanctuaires de déesses du monde grec. Actes du 31e colloque international organisé par l'UMR Halma-Ipel (Université Charles-de-Gaulle/Lille 3, 13-15 Décembre 2007)

Arnold, B., Rev. of Bonfante, ed., The Barbarians of Ancient Europe: Realities and Interactions

Barletta, B.A., Rev. of Ratté, Lydian Architecture: Ashlar Masonry Structures at Sardis

Baughan, E.P., Rev. of Simpson, The Gordion Wooden Objects. Vol. 1, The Furniture from Tumulus MM

Becker, M.J., Rev. of Lazer, Resurrecting Pompeii

Bernbeck, R., Rev. of Schachner, Assyriens Könige an einer der Quellen des Tigris: Archäologische Forschungen im Höhlensystem von Birkleyn und am sogenannten Tigris-Tunnel

Blackwell, N.G., Rev. of Betancourt and Ferrence, eds., Metallurgy: Understanding How, Learning Why. Studies in Honor of James D. Muhly

Bultrighini, I., Rev. of Haysom and Wallensten, eds., Current Approaches to Religion in Ancient Greece: Papers Presented at a Symposium at the Swedish Institute at Athens, 17-19 April 2008

- Rev. of Lohmann and Mattern, eds., Attika: Archäologie einer "zentralen" Kulturlandschaft. Akten der internationalen Tagung vom 18.-20. Mai 2007 in Marburg

Burrell, B., Rev. of Longfellow, Roman Imperialism and Civic Patronage: Form, Meaning, and Ideology in Monumental Fountain Complexes

Butcher, K., Rev. of Tzaferis and Israeli, Paneas

Cadogan, G., Rev. of Gill, Sifting the Soil of Greece: The Early Years of the British School at Athens (1886-1919)

Calkins, R.M., Rev. of Posamentir, The Polychrome Grave Stelai from the Early Hellenistic Necropolis

Campbell, V.L., Rev. of De Simone and Macfarlane, eds., Apolline Project. Vol. 1, Studies on Vesuvius' North Slope and the Bay of Naples

Christakis, K.S., Rev. of Giannopoulou, Pithoi: Technology and History of Storage Vessels Through the Ages

Clarke, J.R., Rev. of Dwyer, Pompeii's Living Statues: Ancient Roman Lives Stolen from Death

Cline, E.H., Rev. of Levy, Historical Biblical Archaeology and the Future: The New Pragmatism

Cummings, C., Rev. of Woolf, Tales of the Barbarians: Ethnography and Empire in the Roman West

D'Ambra, E., Rev. of Platt, Facing the Gods: Epiphany and Representation in Graeco-Roman Art, Literature and Religion

de Grummond, N.T., Rev. of Camporeale and Firpo, eds., Arezzo nell'antichità

Dipla, A., Rev. of Pellegrini, Eros nella Grecia arcaica e classica: Iconografia e iconologia

Donnellan, L., Rev. of Petersen, Cultural Interactions and Social Strategies on the Pontic Shores: Burial Customs in the Northern Black Sea Area c. 550-270 BC

Emme, B., Rev. of Trümper, Die "Agora des Italiens" in Delos: Baugeschichte, Architektur, Ausstattung und Funktion einer späthellenistischen Porticus-Anlage

Fall, P.L., Rev. of Miller, Botanical Aspects of Environment and Economy at Gordion, Turkey

Frangipane, M., Rev. of Carter and Philip, eds., Beyond the Ubaid: Transformation and Integration in the Late Prehistoric Societies of the Middle East

Fullerton, M.D., Rev. of Stansbury-O'Donnell, Looking at Greek Art

Galvao-Sobrinho, C.R., Rev. of Dey, The Aurelian Wall and the Refashioning of Imperial Rome, AD 271-855 
Harding, A., Rev. of Earle and Kristiansen, eds., Organising Bronze Age Societies: The Mediterranean, Central Europe and Scandinavia Compared

Helmers, M., Rev. of Tilley and Bennett, Body and Image: Explorations in Landscape Phenomenology 2

Hoffman, G.L., Rev. of Gruen, Cultural Identity in the Ancient Mediterranean

Höflmayer, F., Rev. of Milevski, Early Bronze Age Goods Exchange in the Southern Levant: A Marxist Perspective Holloway, R.R., Rev. of Dardenay, Les mythes fondateurs de Rome: Images et politique dans l'Occident romain

Hope, V., Rev. of Carroll and Rempel, eds., Living Through the Dead: Burial and Commemoration in the Classical World

Howe, T.N., Rev. of Senseney, The Art of Building in the Classical World: Vision, Craftsmanship, and Linear Perspective in Greek and Roman Architecture

Kardulias, P.N., Rev. of Jennings, Globalizations and the Ancient World

Kielt Costello, S., Rev. of Marchesi and Marchetti (Watson, trans.), Royal Statuary of Early Dynastic Mesopotamia

Kleiner, D.E.E., Rev. of Prusac, From Face to Face: Recarving of Roman Portraits and the Late-Antique Portrait Arts

Kleiner, F.S., Rev. of Müller and Kockel, Die Ehrenbögen in Pompeji

Krentz, P., Rev. of Buraselis and Meidani, eds., Marathon: The Battle and the Ancient Deme

Laurence, R., Rev. of Sewell, The Formation of Roman Urbanism 338-200 B.C.: Between Contemporary Foreign Influence and Roman Tradition

Maeir, A., Rev. of Sasson, Animal Husbandry in Ancient Israel: A Zooarchaeological Perspective on Livestock Exploitation, Herd Management and Economic Strategies

Mattingly, D., Rev. of Eckardt, ed., Roman Diasporas: Archaeological Approaches to Mobility and Diversity in the Roman Empire

McDonald, D.K., Rev. of Cohen and Kangas, eds., Assyrian Reliefs From the Palace of Ashurnasirpal II: A Cultural Biography

McIlwaine, I.C., Rev. of Winckelmann, Letter and Report on the Discoveries at Herculaneum

Mifflin, J., Rev. of Wolfe and Singerman, Mummies in Nineteenth Century America: Ancient Egyptians as Artifacts

Moore, A.M.T., Rev. of Rak, The Rhyton from Danilo: Structure and Symbolism of a Middle Neolithic Cult-Vessel

Moore, M.B., Rev. of Zimmermann-Elseify, Corpus Vasorum Antiquorum. Germany 89. Berlin, Antikensammlung ehemals Antiquarium 12: Attisch Weissgrundige Lekythen

Nakhai, B.A., Rev. of Budin, Images of Woman and Child from the Bronze Age: Reconsidering Fertility, Maternity, and Gender in the Ancient World

Nanoglou, S., Rev. of Lillios and Tsamis, Material Mnemonics: Everyday Memory in Prehistoric Europe

Neils, J., Rev. of Fehr, Becoming Good Democrats and Wives: Civic Education and Female Socialization on the Parthenon Frieze

Osborne, J.F., Rev. of Gilibert, Syro-Hittite Monumental Art and the Archaeology of Performance

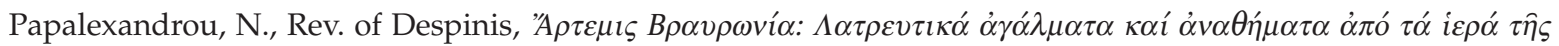

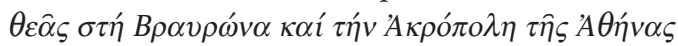

Peña, J.T., Rev. of Reynolds, Hispania and the Roman Mediterranean, AD 100-700: Ceramics and Trade

Peterson, J., Rev. of Finlayson and Warren, Changing Natures: Hunter-Gatherers, First Farmers and the Modern World Pevnick, S.D., Rev. of Calder, Cruelty and Sentimentality: Greek Attitudes to Animals, 600-300 BC

Poehler, E., Rev. of Jansen, Koloski-Ostrow, and Moormann, eds., Roman Toilets: Their Archaeology and Cultural History

Pollock, S., Rev. of Frachetti, Pastoralist Landscapes and Social Interaction in Bronze Age Eurasia

Prag, K., Rev. of Richard, Long, Jr., Holdorf, and Peterman, eds., Khirbat Iskandar: Final Report on the Early Bronze IV Area C "Gateway" and Cemeteries

Radner, K., Rev. of Barjamovic, A Historical Geography of Anatolia in the Old Assyrian Colony Period

Richardson, M.B., Rev. of Butz, The Art of the Hekatompedon Inscription and the Birth of the Stoikhedon Style

Rohl, D.J., Rev. of Cosh and Neal, Roman Mosaics of Britain. Vol. 4, Western Britain

Rojas, F., Rev. of D'Andria and Romeo, eds., Roman Sculpture in Asia Minor: Proceedings of the International Conference to Celebrate the 50th Anniversary of the Italian Excavations at Hierapolis in Phrygia, Held on May 24-26, 2007, in Cavallino (Lecce)

Roller, D.W., Rev. of Sidebotham, Berenike and the Ancient Maritime Spice Route

Rotroff, S.I., Rev. of Horejs, Jung, and Pavúk, eds., Analysing Pottery: Processing, Classification, Publication 
Schon, R., Rev. of Terrenato and Haggis, eds., State Formation in Italy and Greece: Questioning the Neoevolutionist Paradigm

Scotton, P.D., Rev. of Lindblom and Wells, eds., Mastos in the Berbati Valley: An Intensive Archaeological Survey

Serwint, N., Rev. of Jeammet, Tanagras: Figurines for Life and Eternity. The Musée du Louvre's Collection of Greek Figurines

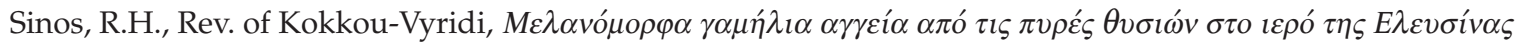

Stewart, A., Rev. of Santi, I frontoni arcaici dell'Acropoli di Atene

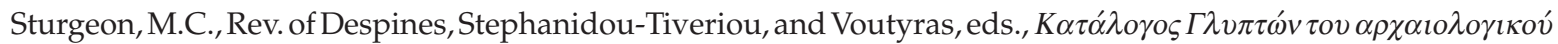

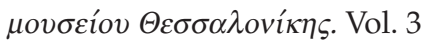

Tsetskhladze, G., Rev. of Dietler, Archaeologies of Colonialism: Consumption, Entanglement, and Violence in Ancient Mediterranean France

Tuck, A., Rev. of de Grummond and Edlund-Berry, eds., The Archaeology of Sanctuaries and Ritual in Etruria

Turfa, J.M., Rev. of Gabrielli, Ceramica etrusco-corinzia del Museo archeologico di Tarquinia

Uhlenbrock, J.P., Rev. of Bookidis, The Sanctuary of Demeter and Kore: The Terracotta Sculpture

Whitehead, J., Rev. of Lulof and Rescigno, eds., Deliciae Fictiles IV: Architectural Terracottas in Ancient Italy. Images of Gods, Monsters and Heroes

Winkes, R., Rev. of Caneva, Il codice botanico di Augusto: Roma, Ara Pacis. Parlare al popolo attraverso le immagini della natura/The Augustus Botanical Code: Rome, Ara Pacis. Speaking to the People Through the Images of Nature

Younger, J.G., Rev. of Duhoux and Morpurgo Davies, eds., A Companion to Linear B: Mycenaean Greek Texts and Their World. Vol. 2

, Rev. of Pini, Aegean and Cypro-Aegean Non-Sphragistic Decorated Gold Finger Rings of the Bronze Age

Zagermann, M., Rev. of Collins and Allason-Jones, eds., Finds from the Frontier: Material Culture in the 4th-5th Centuries 